\title{
POSSIBILITY OF USING THE EXPANDED POLYSTYRENE AND RAPE STRAW TO THE MANUFACTURE OF LIGHTWEIGHT PARTICLEBOARDS
}

\author{
Dorota Dziurka $^{1, \AA}$, Radoslaw Mirski ${ }^{1}$, Dorota Dukarska ${ }^{1}$,Adam Derkowski
}

\begin{abstract}
The study investigated the possibility of using rape straw and expanded polystyrene for the production of low density particleboards. Particleboards with the core layer made of wood chips or rape straw, partly substituted with polystyrene (7\%), were manufactured within the density range of $500-650 \mathrm{~kg} /$ $\mathrm{m}^{3}$, and resinated with MUF resin. Our study confirmed that wood chip-expanded polystyrene (WP) and wood chip-rape straw-expanded polystyrene boards (WRP), of density reduced to $600 \mathrm{~kg} / \mathrm{m}^{3}$, met the mechanical requirements of the subject standard for boards intended for interior design (including furniture) and used in dry conditions. However, further density reduction required an increased resination of the core layer.
\end{abstract}

Keywords: Lightweight boards, mechanical properties, MUF resin, polystyrene, rape.

\section{INTRODUCTION}

One of the problems impeding the development of particle board industry is insufficient supply of wood. This difficulty is due to a growing demand for wood from various branches of the wood processing industry, as well as the energy sector that uses the wood as biomass, as recommended in the EU requirements concerning the energy from renewable sources. Efficient management of lumber may involve its reduced consumption in the manufacture of wood-based products, through the production of wood-based materials with a reduced density, as compared to the density of the standard boards in the respective groups of materials. A growing tendency is observed towards reducing the density of particleboards, particularly those intended for the manufacture of furniture. Apart from ecological factors, other important considerations involve economic factors, such as reducing the cost of transportation and installation, and ergonomic factors, i.e., easier assembly or improved functionality.

The literature shows that low density particleboards may be produced from different tree species, and the choice of a specific species is determined by its wood density and availability within a particular area. So far, low density particleboards and MDF have been manufactured from the wood of the following species: birch, beech, spruce, poplar, pine, shorea, balsa, Keruing, cypress, Cunninghamia, Japanese cedar or paulownia (Clad 1982, Kawai et al. 1985, 1986, Suda et al. 1987a, Suda et al. 1987b, Suematsu and Okuma 1988, Suematsu and Okuma 1989, Chen and Wu 1993, Qiaoi et al. 2000, Clad and Pommer 1980, Kalaycioglu et al. 2005, Borysiuk et al. 2007).

\footnotetext{
Poznań University of Life Sciences, Faculty of Wood Technology, Department of Wood-Based Materials, Poznań , Poland

^ Corresponding author: ddziurka@up.poznan.pl

Received: 07.07.2014 Accepted: 04.03.2015
} 
Apart from wood, low density particleboards may also be produced from annual plants. Particles of these plants are characterized by limited swelling and relatively high hardness, elasticity, smoothness, and slenderness (Kozłowski et al. 2001). Moreover, they usually exhibit lower density than wood, thereby enabling the production of materials within a wide range of densities - from 300 to $750 \mathrm{~kg} / \mathrm{m}^{3}$. The subject literature shows that the following annual and multiannual plants have been used for these particleboards production: flax, hemp, jute, bagasse, shives of flax, kenaf, cotton and sunflower stalks, stems, cobs, husks and even roasted corn, wheat straw, miscanthus and bamboo (Sellers et al. 1993, Kozłowski et al. 2001, Wang and Sun 2002, Xu et al. 2004, Meinlschmidt et al. 2008, Czechowska et al. 2010, Arruda et al. 2011, Araújo et al. 2011, Bekhta et al. 2013). It should be emphasized that the above mentioned plants may provide a potential raw material for the production of low density $(100-300$ $\mathrm{kg} / \mathrm{m}^{3}$ ) particleboards, however, only those boards intended for use as insulating material or core layers of laminated composite materials (Sellers et al. 1993, Xu et al. 2004). Attempts at using sunflower and corn stalks, either alone or in combination with spruce and poplar wood, yielded unsatisfactory results. It was found (Meinlschmidt et al. 2008), that only single-layer boards made from sunflower stalks met the requirements for $\mathrm{P} 2$ boards, but only with respect to tensile strength.

On the market in terms of lightweight boards the cellular wood panels are dominant. There is a product known and used in furniture industry and door production for many years. In this case, thanks to its layer structure with the core in the form of the so-called honey comb, we obtain a maximal weight reduction without any deterioration of load bearing capacity, rigidity or other functions of the structure. However, they are not universal materials and their most significant drawbacks include the necessity to have specialist machines and equipment, the application of special hardware as well as considerable labour consumption. It seems that these problems can be free the boards with foamed polystyrene filling. This interesting solution was proposed by BASF company, who has developed an innovative wood-based material (Kaurit ${ }^{\circledR}$ Light) that may revolutionize the furniture market. The particleboards manufactured in this technology are characterized by a density of $450 \mathrm{~kg} / \mathrm{m}^{3}$, while maintaining the same strength as standard particleboards with a density of $650 \mathrm{~kg} / \mathrm{m}^{3}$. Such a significant density reduction is possible due to the use of foam polymer beads $(15-25 \mathrm{~kg})$, replacing $200 \mathrm{~kg}$ of wood per each cubic meter of wood material. due to the more uniform structure. The polystyrene beads will fill up the empty spaces, making the structure of the core layer more uniform, which would undoubtedly improve the board stiffness and its overall strength.

Additionally, taking into account the fact that the annual plants characterized by lower density than wood, which allow to achieve a lower density of final product, in this study it was decided to investigate the possibility of manufacturing low density particleboards, using rape straw and expanded polystyrene, resinated with melamine-urea-formaldehyde resin (MUF).

\section{MATERIALS AND METHODS}

The particleboards were manufactured using wood pine chips, rape straw particles and expanded polystyrene beads 2 to $9 \mathrm{~mm}$ in size. The expanded polystyrene beads (EPS-035) used in this study were made of foamed polystyrene - an intermediate product for the production of polystyrene insulation boards. The properties of this material are as follows: compressive strength $-150 \mathrm{kPa}$, density $-25 \mathrm{~kg} /$ $\mathrm{m}^{3}$, thermal conductivity $-0,035 \mathrm{~W} / \mathrm{m} \cdot \mathrm{K}$ Particles of wood and rape straw were obtained by two-stage fragmentation on a shredder cutter and their basic parameters are presented in table 1. 
Table 1. Basic parameters of the raw lignocellulosic materials used for the production of lightweight boards.

\begin{tabular}{|c|c|c|c|}
\hline Property & Equation & Pine chips & Rape straw \\
\hline Moisture content, $\%$ & - & 2,9 & 1,5 \\
\hline Average dimensions, $\mathrm{mm}$ & - & $12,45 \times 1,87 \times 0,83$ & $\begin{array}{c}15,02 \times 1,30 \times \\
0,97\end{array}$ \\
\hline Slenderness ratio & $\lambda=\frac{l}{a}$ & 15 & 15,5 \\
\hline Flatness & $\psi=\frac{b}{a}$ & 2,3 & 1,3 \\
\hline Specific surface, $\mathrm{m}^{2} / \mathrm{kg}$ & $F_{w}=\frac{2}{\rho_{0}}\left[\frac{1}{l}+\frac{1}{b}+\frac{1}{a}\right]$ & 8,09 & 12,44 \\
\hline
\end{tabular}

The boards were resinated with melamine-urea-formaldehyde resin (MUF), intended for the manufacture of waterproof wood-based materials, and having the following characteristics: molar ration M:U:F 1:1:3.8, dry matter content $69,5 \%$, gel time $-128 \mathrm{~s}$, density $-1,29 \mathrm{~g} / \mathrm{cm}^{3}$, viscosity $-480 \mathrm{mPa} \cdot \mathrm{s}$.

For the study purposes three-layer particleboards comprising wood chips and expanded polystyrene, and wood chips, rape straw and expanded polystyrene were manufactured, with the density range of $650-500 \mathrm{~kg} / \mathrm{m}^{3}$, and a thickness of $19 \mathrm{~mm}$. The core layer was made of rape straw particles or wood chips and the outer layers of fine chips. Additionally, $7 \%$ of the core layer chips were substituted with expanded polystyrene beads. The boards were pressed for $360 \mathrm{~s}$, and the resination rate was $8 \%$ and $14 \%$, for the core and outer layers, respectively. Reference boards were those in which the core layer was made up of wood chips or rape straw alone. Additional boards, with the resination rate of the core layer chips amounting to 10,12 and $14 \%$, were manufactured for the density of $550 \mathrm{~kg} / \mathrm{m}^{3}$. All boards were pressed at a temperature of $200^{\circ} \mathrm{C}$, and a pressure of 2,5 $\mathrm{MPa}$. The boards were produced in 2 replications. The specific pressing parameters are also given in table 2 and on figure 1 are presented density profiles of boards with a density $550 \mathrm{~kg} / \mathrm{m}^{3}$.

Table 2. The specific pressing parameters of boards.

\begin{tabular}{|c|c|c|c|c|c|}
\hline \multicolumn{2}{|c|}{ Target density } & $650 \mathrm{~kg} / \mathrm{m}^{3}$ & $650 \mathrm{~kg} / \mathrm{m}^{3}$ & $600 \mathrm{~kg} / \mathrm{m}^{3}$ & $550 \mathrm{~kg} / \mathrm{m}^{3}$ \\
\hline \multicolumn{2}{|l|}{ Layers } & 3 & 3 & 3 & 3 \\
\hline \multicolumn{2}{|c|}{ Surface layers } & fine chips & fine chips & fine chips & fine chips \\
\hline \multicolumn{2}{|l|}{ Core layer } & wood chips & $\begin{array}{c}\text { wood chips/ } \\
\text { polystyrene } 7 \%\end{array}$ & $\begin{array}{c}\text { wood chips/ } \\
\text { polystyrene } 7 \%\end{array}$ & $\begin{array}{l}\text { wood chips/ } \\
\text { polystyrene } 7 \%\end{array}$ \\
\hline \multicolumn{2}{|l|}{ Core layer } & rape straw & $\begin{array}{c}\text { rape straw/ } \\
\text { polystyrene } 7 \%\end{array}$ & $\begin{array}{c}\text { rape straw/ } \\
\text { polystyrene } 7 \%\end{array}$ & $\begin{array}{c}\text { rape straw/ } \\
\text { polystyrene } 7 \%\end{array}$ \\
\hline \multirow{2}{*}{$\begin{array}{l}\text { Resination } \\
\text { rate }\end{array}$} & Surface & $14 \%$ & $14 \%$ & $14 \%$ & $14 \%$ \\
\hline & Core & $8 \%$ & $8 \%$ & $8 \%$ & $\begin{array}{lll}10 & 12 & 14\end{array}$ \\
\hline \multicolumn{3}{|c|}{ Pressing time } & \multicolumn{2}{|r|}{$360 \mathrm{~s}$} & \\
\hline \multicolumn{3}{|c|}{$\begin{array}{l}\text { Pressing } \\
\text { temperature }\end{array}$} & \multicolumn{2}{|r|}{$200^{\circ} \mathrm{C}$} & \\
\hline \multicolumn{3}{|c|}{ Unit pressure } & \multicolumn{2}{|c|}{$2,5 \mathrm{MPa}$} & \\
\hline
\end{tabular}


a)

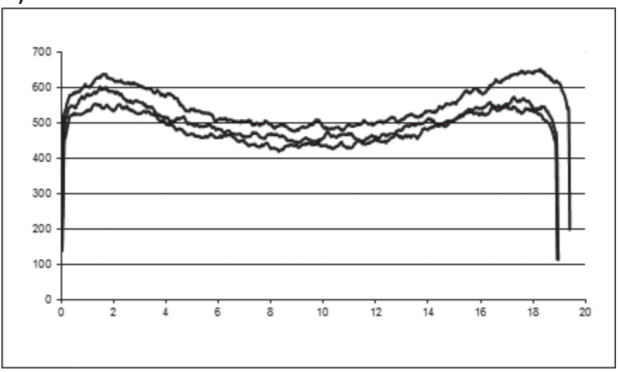

b)

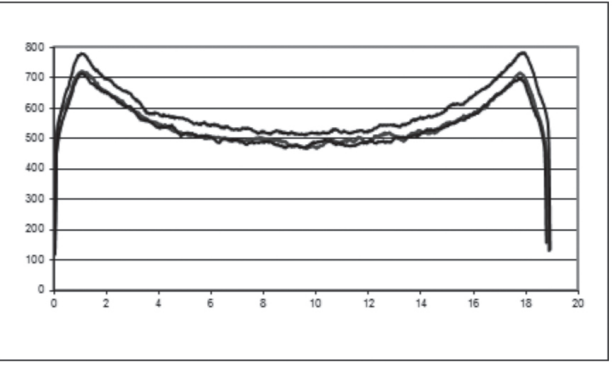

Figure 1. Density profiles the boards with density $550 \mathrm{~kg} / \mathrm{m}^{3}$.

a) Wood chip-expanded polystyrene

b) WRP wood chip-rape straw-expanded polystyrene.

Properties of the manufactured boards were tested in accordance with the relevant standards:

- $\quad$ modulus of rupture (MOR) and modulus of elasticity (MOE) - EN 310,

- $\quad$ internal bond (IB) - EN 319,

- $\quad$ internal bond after the boiling test (V100) - EN 1087-1,

- $\quad$ swelling in thickness after immersion in water (TS) - EN 317, and additionally water absorption after immersion in water (WA).

12 samples per board for each property (a total of 24) were tested in order to evaluate the mean value and standard deviation.

\section{RESULTS AND DISCUSSION}

The results of mechanical properties and water resistance tests for the manufactured wood chipexpanded polystyrene (WP), and wood chip-rape straw-expanded polystyrene particleboards (WRP), depending on their density and resination rate, are shown in tables 3 and 4.

As might have been expected, reduced density of the boards was accompanied by lower static bending strength, and this value was independent of the core layer composition (rape particles+expanded polystyrene or wood chips+expanded polystyrene) (Figure 2). The study outcomes also showed (Table 3, Figure 2) that in both cases the addition of expanded polystyrene to the core layer resulted in increased static bending strength, as compared to the relevant control boards. 
Table 3. Mechanical properties and water resistance of wood chip-expanded polystyrene and wood chip-rape straw-expanded polystyrene boards depending on their density.

\begin{tabular}{|c|c|c|c|c|c|c|}
\hline Density & MOR & MOE & IB & V100 & TS & WA \\
\hline $\mathrm{kg} / \mathrm{m}^{3}$ & \multicolumn{4}{|c|}{$\mathrm{MPa}$} & \multicolumn{2}{|c|}{$\%$} \\
\hline \multicolumn{7}{|c|}{ Wood chip-expanded polystyrene board } \\
\hline \multirow{2}{*}{$\begin{array}{l}\text { Control } \\
\text { board* }\end{array}$} & $15,2 * *$ & 2810 & 0,62 & 0,21 & 24,7 & 62,1 \\
\hline & $1,02 * * *$ & 160 & 0,073 & 0,017 & 1,32 & 3,36 \\
\hline \multirow{2}{*}{650} & 17,6 & 2850 & 0,67 & 0,16 & 22,7 & 54,4 \\
\hline & 1,05 & 130 & 0,066 & 0,013 & 1,19 & 5,55 \\
\hline \multirow{2}{*}{600} & 13 & 2400 & 0,56 & 0,15 & 20,9 & 61,2 \\
\hline & 0,73 & 110 & 0,070 & 0,015 & 0,52 & 3,72 \\
\hline \multirow{2}{*}{550} & 11,9 & 2290 & 0,47 & 0,11 & 19,8 & 69,4 \\
\hline & 0,90 & 90 & 0,066 & 0,039 & 0,51 & 2 \\
\hline \multirow{2}{*}{500} & 10,1 & 2080 & 0,41 & 0,09 & 19,2 & 76,6 \\
\hline & 0,40 & 110 & 0,072 & 0,013 & 0,53 & 3,43 \\
\hline \multicolumn{7}{|c|}{ Wood chip-rape straw-expanded polystyrene board } \\
\hline \multirow{2}{*}{$\begin{array}{l}\text { Control } \\
\text { board* }\end{array}$} & 14,2 & 2650 & 0,43 & 0,04 & 28 & 82,4 \\
\hline & 0,81 & 140 & 0,031 & - & 1,52 & 2,43 \\
\hline \multirow{2}{*}{650} & 15,9 & 2710 & 0,46 & 0,03 & 26,2 & 83,2 \\
\hline & 0,79 & 140 & 0,022 & - & 1,43 & 4,71 \\
\hline \multirow{2}{*}{600} & 13,2 & 2100 & 0,43 & - & 24,9 & 84,3 \\
\hline & 1,04 & 370 & 0,022 & - & 2,48 & 5,42 \\
\hline \multirow{2}{*}{550} & 11,5 & 2050 & 0,41 & - & 20,9 & 86,4 \\
\hline & 0,66 & 200 & 0,022 & - & 0,90 & 6,91 \\
\hline \multirow{2}{*}{500} & 10,3 & 1980 & 0,29 & - & 19,2 & 89 \\
\hline & 1 & 120 & 0,021 & - & 1,17 & 3,15 \\
\hline
\end{tabular}

$*-650 \mathrm{~kg} / \mathrm{m}^{3}, 100 \%$ wood chips or rape straw particles, $* *$ - mean value, $* * *$ - standard deviation

The strength of the polystyrene-supplemented wood chip-rape straw boards and wood chip boards, with the density of $650 \mathrm{~kg} / \mathrm{m}^{3}$, was respectively $10 \%$ and $12 \%$ higher than of the control boards with the same density but without polystyrene. These results may be explained by more uniform board structure evidenced in the cross section. It seems that the polystyrene beads fill up the empty spaces, making the structure of the core layer more uniform, which would undoubtedly improve the board stiffness and its overall strength. However, this positive effect of polystyrene, manifested by increased rigidity of the board core, was counterbalanced by further reduction in the board density.

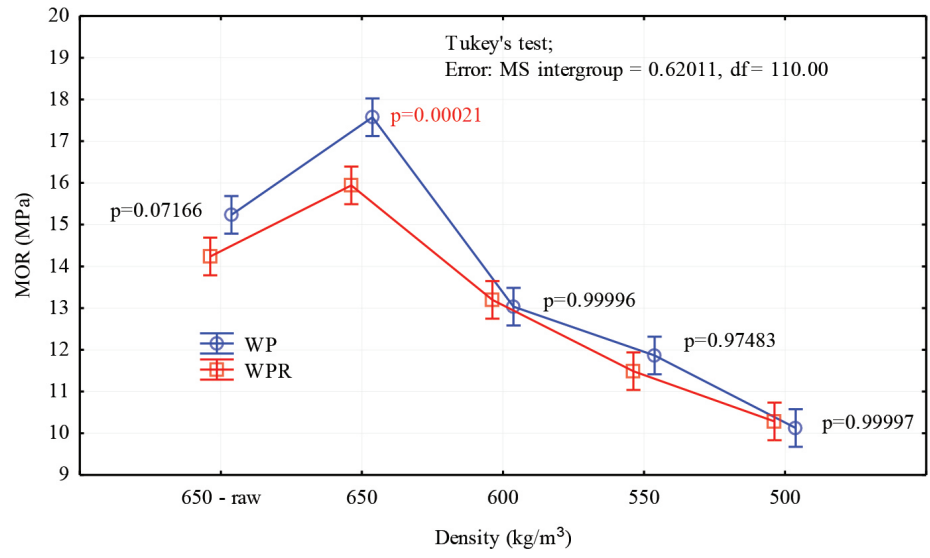

Figure 2. Effect of density on the properties of WP and WRP boards. 
Along with lowering the overall density, the density of the outer layers, responsible for the static bending strength and carrying two thirds of the board's resination, was decreasing as well. The modulus of elasticity tests yielded similar results. According to EN 312, both types of boards with a density of $600-650 \mathrm{~kg} / \mathrm{m}^{3}$, met the requirements concerning bending strength and modulus of elasticity for P2 boards, i.e., boards intended for interior design (including furniture) used in dry conditions (13 MPa and $1600 \mathrm{MPa}$ according to EN 312, for MOR and MOE, respectively).

The study demonstrated that the manufactured boards exhibited high tensile strength perpendicular to the board plane. It is worth mentioning that as far as this parameter was concerned, the performance of WRP boards was much worse than that of the corresponding WP boards (Figure 3).

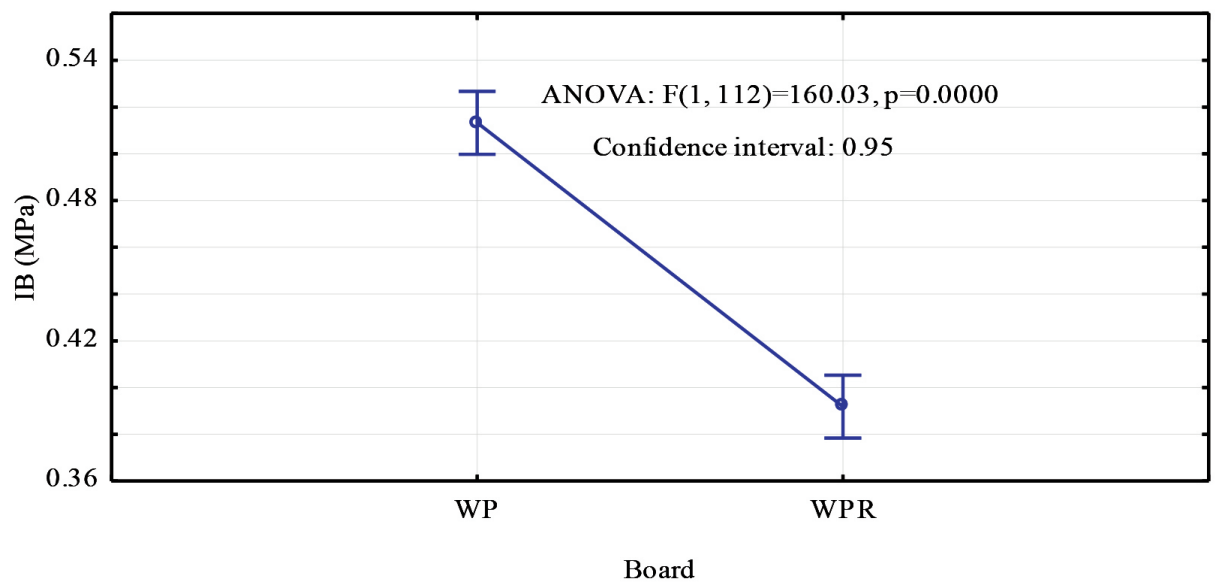

Figure 3. Effect of the core layer composition and mean board density on the tensile strength perpendicular to the board plane.

It seems that this situation may be ascribed to the type of the resin used. It is well known that amino resins exhibit much weaker adhesion to the particles obtained from annual plants than to wood chips. In comparison to wood rape straw contains less cellulose and lignin, but more hemicelluloses, mineral compounds and waxes (Dziurka et al. 2005). Undoubtedly cellulose has an advantageous effect on strength properties of boards; however, a bigger role is played by the contents of extraction substances, as they determine bond quality. That amounts of extraction substances in rape straw are higher than the contents of such substances in wood. These substances hindering resination and have a disadvantageous effect on the gluability of rape straw particles, even in case when typical polar wood adhesives are applied. Therefore, the strength of wood chip-expanded polystyrene boards, despite partial substitution of wood chips with polystyrene and a significant reduction in density (down to $500 \mathrm{~kg} / \mathrm{m}^{3}$ ), still exceeded the value recommended for P2 boards ( $0,35 \mathrm{MPa}$ according to EN 312). It seems, however, that in the case of WRP boards, the use of isocyanate-based adhesives that bond to these types of particles through chemical reactions with the appropriate functional groups, would significantly improve the board strength. Therefore, while using the MUF resin for these types of particles, and considering their partial substitution with polystyrene, the resination of the board core layer should be markedly increased.

The data on swelling and water absorption for both types of boards, presented in table 3 , indicated that reduced density was accompanied by declined swelling after 24 hours of soaking in water. However, it seems that this effect was rather due to more porous structure of the board than partial substitution of the core layer chips with polystyrene beads of high hydrophobicity. It is known that water, while penetrating into a material with a loose structure, fills the empty spaces without affecting the material thickness. However, this resulted in a significant gain of the board weight, based on which the water absorption was determined. On the other hand, the tests on water resistance, measured as the tensile 
strength perpendicular to the board plane after the cooking test, showed that the WP displayed higher strength after the V100 test (Table 3). Although the strength of the lowest density board was half of the strength of the board made of wood chips alone, it was still within the range recommended in the standard for P3 boards, i.e. boards used in humid conditions ( $0,08 \mathrm{MPa}$ according to EN 312). Thus, it may be concluded that the addition of polystyrene worsened the strength of the boards, but thanks to the type of the resin used, it still remained sufficiently high. As might have been expected, poor adhesion of the condensation resins to the particles of annual plants resulted in low water resistance of wood chip-rape straw-expanded polystyrene boards.

To sum up, our study confirmed that WP and WRP boards, of density reduced to $600 \mathrm{~kg} / \mathrm{m}^{3}$, met the mechanical requirements for MOR, MOE and IB described in the subject standard for the boards intended for interior design (including furniture) and used in dry conditions (P2). It was also shown that further reduction in density (down to $550 \mathrm{~kg} / \mathrm{m}^{3}$ ) was possible, but required increasing the resination of the core layer chips up to $14 \%$ (Table 4 ).

Table 4. Mechanical properties and water resistance of wood chip-expanded polystyrene and wood chip-rape straw-expanded polystyrene boards depending on the resination of their core layers.

\begin{tabular}{|ccccccc|}
\hline $\begin{array}{c}\text { Resination of } \\
\text { the core layer } \\
\text { with MUF }\end{array}$ & MOR & MOE & IB & V100 & TS & WA \\
\hline$\%$ & \multicolumn{7}{c|}{ MPa } \\
\hline \multicolumn{7}{c|}{ Wood chip-expanded polystyrene board } \\
\hline \multirow{2}{*}{8} & $11,9 *$ & 2290 & 0,47 & 0,11 & 19,8 & 69,4 \\
& $0,81 * *$ & 70 & 0,031 & 0,020 & 0,57 & 3,08 \\
\hline \multirow{2}{*}{10} & 12,5 & 2330 & 0,49 & 0,16 & 18,5 & 74,9 \\
& 0,80 & 110 & 0,044 & 0,010 & 0,75 & 2,11 \\
\hline \multirow{2}{*}{12} & 12,8 & 2370 & 0,52 & 0,20 & 18,6 & 73,5 \\
& 0,75 & 100 & 0,045 & 0,030 & 0,48 & 2,84 \\
\hline \multirow{2}{*}{14} & 13,3 & 2490 & 0,61 & 0,21 & 18,8 & 71,1 \\
& 0,91 & 140 & 0,037 & 0,022 & 0,73 & 2,57 \\
\hline \multirow{2}{*}{8} & Wood chip-rape straw-expanded polystyrene board & \\
\hline \multirow{2}{*}{10} & 11,5 & 2050 & 0,41 & - & 20,8 & 86,4 \\
& 1,20 & 160 & 0,033 & - & 1,03 & 6,69 \\
\hline \multirow{2}{*}{12} & 12,6 & 2210 & 0,33 & - & 18,3 & 87,2 \\
& 1,25 & 160 & 0,036 & - & 0,72 & 5,82 \\
\hline \multirow{2}{*}{14} & 13 & 2280 & 0,38 & - & 17,5 & 85,1 \\
& 0,90 & 100 & 0,048 & - & 0,69 & 4,80 \\
\hline
\end{tabular}

* - mean value, ** - standard deviation

The Tukey's test results revealed that the properties of the WP and WRP boards with a density of $550 \mathrm{~kg} / \mathrm{m}^{3}$ and $14 \%$ resination were similar to the boards with a density of $650 \mathrm{~kg} / \mathrm{m}^{3}$ and $8 \%$ resination, particularly for MOR, MOE, IB, and V100 (p close to 1, Figures 4 and 5). 


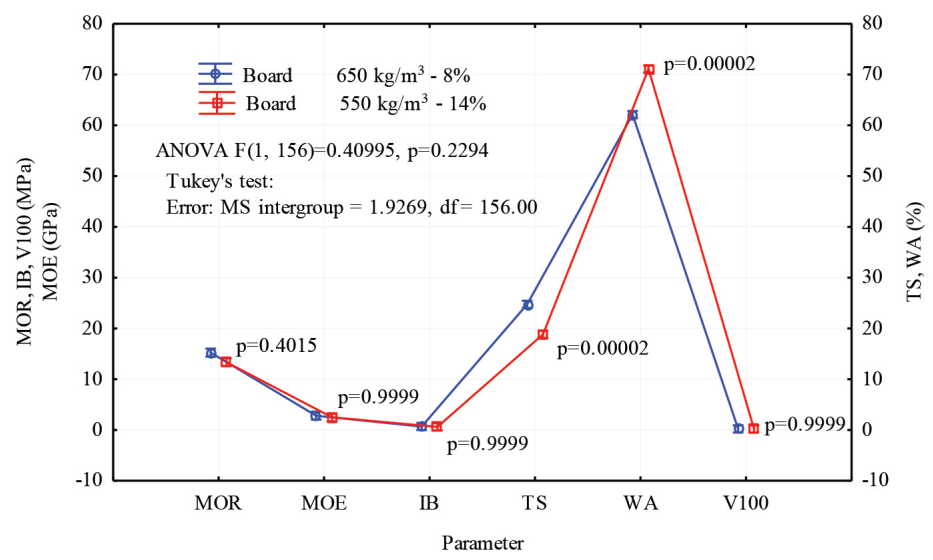

Figure 4. Results of the post hoc test (Tukey's test) for WP boards with a density of 650 and $550 \mathrm{~kg} / \mathrm{m}^{3}$.

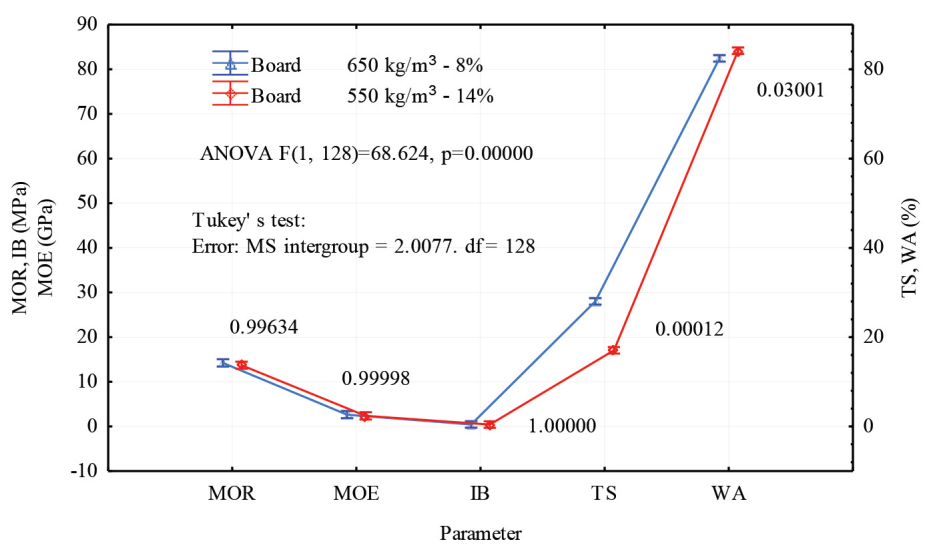

Figure 5. Results of the post hoc test (Tukey's test) for WPR boards with a density of 650 and $550 \mathrm{~kg} / \mathrm{m}^{3}$.

\section{CONCLUSIONS}

Expanded polystyrene beads may be used as a partial substitution of wood chips and rape straw particles in the core layer of particleboards resinated with MUF resin.

Reduced density of the boards was accompanied by deterioration of their properties, however, the tensile strength and modulus of elasticity in the WRP boards were higher than in the corresponding WP ones.

It was found that the WP and WRP boards, of density reduced to $600 \mathrm{~kg} / \mathrm{m}^{3}$, met the mechanical requirements described in the subject standard for the boards intended for interior design (including furniture) and used in dry conditions. However, further density reduction required an increased resination of the core layer. 


\section{REFERENCES}

de Araújo, P.C.; Arruda, L.M.; Del Menezzi, C.H.S.; Teixeira, D.E.; de Souza, M.R. 2011. Lignocellulosic composites from Brazilian giant bamboo (Guadua magna). Part 2: Properties of cement and gypsum bonded particleboards. Maderas. Ciencia y tecnología 13 (3): 297-306.

Arruda, L.M.; Del Menezzi, C.H.S.; Teixeira, D.E.; de Araújo, P.C. 2011. Lignocellulosic composites from brazilian giant bamboo (Guadua magna). Part 1: Properties of resin bonded particleboards. Maderas. Ciencia y tecnología 13(1): 49-58.

Bekhta, P.A.; Korkut, S.; Hiziroglu, S. 2013. Effect of Pretreatment of Raw Material on Properties of Particleboard Panels Made from Wheat Straw. BioResources 8(3): 4766-4774.

Borysiuk, P.; Nicewicz, D.; Pawlicki, J.; Klimczewski, M. 2007. The influence of the type and preparation of lingo-cellulose fibres on the properties of MDF. Wood Research 52 (4): 79-88.

Chen, T.Y.; Wu, J.P. 1993. Studies on the manufacturing of particleboard from fast-growing tree species (IV-1) - Effect of particleboard density on the properties of the PMDI and UF glue bonded particleboard. Forest Product Industry 12: 72-88.

Clad, W. 1982. Die Rohdichtesenkung bei Spanplatten, Eine Literaturübersicht. Holz als Roh und Werkstoff 40: 387-393.

Clad, W.; Pommer, E.H. 1980. Spanplatten aus Kiri (Paulownia tomentosa, Fam. Scrophulariaceae). Holz als Roh und Werkstoff 38: 385-391.

Czechowska, J.; Borysiuk, P.; Mamiński, M.; Jaskółowski, W. 2010. Some properties of lowdensity particleboards filled with pop-corn. Annals of Warsaw University of Life Science - SGGW. Forest and Wood Technology 70: 52-56.

Dziurka, D.; Mirski, R.; Łęcka, J. 2005. Properties of boards manufactured from rape straw depending on the type of the binding agent, EJPAU 8(3).

European Standard EN 1087-1. 1995. Particleboards. Determination of moisture resistance - Part 1: Boil Test. CEN European Committee for Standardisation.

European Standard EN 310. 1993. Wood-Based Panels. Determination of modulus of elasticity in bending and of bending strength. CEN European Committee for Standardisation.

European Standard EN 317. 1993. Particleboards and fibreboards. Determination of swelling in thickness after immersion in water. CEN European Committee for Standardisation.

European Standard EN 319. 1993. Particleboards and Fibreboards. Determination of tensile strength perpendicular to the plane of the board. CEN European Committee for Standardisation.

Kalaycioglu, H.; Deniz, I.; Hiziroglu, S. 2005. Some of the properties of particleboard made from paluownia. Journal of Wood Science 51: 410-414.

Kawai, S.; Sasaki, H.; Nakaji, M.; Makiyama, S.; Morita, S. 1985. Physical properties of low density particleboard. Wood Research 72: 27-36. 
Kawai, S.; Suda, H.; Nakaji, M.; Sasaki, H. 1986. Production technology for low-density particleboard II. Effects of particle moisture content and resin content on board properties. Journal Japan Wood Research Society 2: 876-882.

Kozłowski, R.; Mieleniak, B.; Przepiera, A. 2001. Annual plant waste as raw material for the production of lignocellulosic boards [in Polish]. Przemysł Drzewny 3: 17-20.

Meinlschmidt, P.; Schirp, A.; Dix, B.; Thole, V.; Brinker, N. 2008. Agricultural residues with light parenchyma cells and expandable filler materials for the production of lightweight particleboards. In: Proceedings of the International Panel Products Symposium, $24^{\text {th }}-26^{\text {th }}$ September, Finland, $179-188$.

Qiao, J.L.; Xiu, S.H.; Chun, Ch.W.; Yong, H. 2000. Manufacturing of nonpoisonous low-density Chinese fir particleboard bonded with diisocyanate adhesive. China Wood Industry 14: 27-30.

Sellers, T.Jr.; Miller, G.D.; Fuller, M.J. 1993. Kenaf core as a board raw material. Forest Products Journal 43: 69-71.

Suda, H.; Kawai, S.; Sasaki, H. 1987a. Production technology for low-density particleboard IV. Effects of particle density and compaction ratio on board properties. Journal Japan Wood Research Society 33: 385-392.

Suda, H.; Kawai, S.; Sasaki, H. 1987b. Production technology for low-density particleboard III. Effect of particle geometry on board properties. Journal Japan Wood Research Society 33: 376-384.

Suematsu, A.; Okuma, M. 1988. Mechanism of low-density particleboard formation I. Hot-pressing process and mechanism of board formation. Journal Japan Wood Research Society 34: 820-827.

Suematsu, A.; Okuma, M. 1989. Mechanism of low-density particleboard formation II. Hot-pressing conditions and hygroscopic thickness swelling. Journal Japan Wood Research Society 35: 107-115.

Wang, D.; Sun, X. 2004. Low density particleboard from wheat straw and corn pith. Industrial Crops and Products 15: 43-50.

Xu, J.; Sugawara, R.; Widyorini, R.; Han, G.; Kawai, S. 2004. Manufacture and properties of low-density binderless particleboard from kenaf core. Journal of Wood Science 50: 62-67. 